\title{
INTEGRATED WATER RESOURCES MANAGEMENT FOR SUSTAINABLE IRRIGATION AT THE BASIN SCALE
}

\author{
Max Billib ${ }^{1}$, Karin Bardowicks' ${ }^{1}$, and José Luis Arumí
}

\begin{abstract}
The objective of this paper is to review the state of art on integrated water resources management (IWRM) approaches for sustainable irrigation at the basin scale under semi-arid and arid climatic conditions, with main emphasis on Latin America, but including case studies of other semi-arid and arid regions in the world. In Latin America the general concept of IWRM has proved to be hard to implement. Case studies recommend to develop the approach from lower to upper scale and oriented at the end-user. As IWRM is an interdisciplinary approach and used for very different objectives, the main emphasis is given to IWRM approaches for sustainable irrigation and their environmental aspects. The review shows that in Latin America the environmental impact is mostly analysed at the field level, the impact on the whole basin is less considered. Many publications present the development of models, advisory services and tools for decision support systems at a high technical level. Some papers present studies of environmental aspects of sustainable irrigation, especially for salt affected areas. Multi-criteria decision making models are developed for irrigation planning and irrigation scenarios are used to show the impact of different irrigation management decision. In general integrated approaches in Latin America are scarce.
\end{abstract}

Key words: water resources management, basin, sustainability, irrigation.

\section{INTRODUCTION}

Most of the projected global population increases will take place in third world countries that already suffer from water, food, and health problems. Increasingly, the various water users like municipal, industrial, and agricultural sectors must be coordinated with, and integrated into, the overall water management of the region. Sustainability, public health, environmental protection, and economics are key factors. In irrigated areas, groundwater levels may have to be controlled with drainage or pumped well systems to prevent waterlogging and salinisation of soil. Salty drainage waters must then be handled in an ecologically responsible way. Water short countries can save water by importing most of their food and electric power from other countries with more water and local water can then be used for purposes with higher social, ecological, or economic returns or saved for the future (Bouwer, 2002).

${ }^{1}$ Leibniz Universität Hannover, Institute of Water Resources Management, Hydrology and Agricultural Hydraulic Engineering, Appelstr. 9 a, D-30167 Hannover, Germany.

(billib@iww.uni-hannover.de; bardowicks@iww.uni-hannover.de). ${ }^{2}$ Universidad de Concepción, Facultad de Ingeniería Agrícola, Av. Vicente Méndez 595, Chillán, Chile (jarumi@udec.cl).
Therefore sustainable water resources management for irrigation is not only an objective on the farm level but also an overall goal at the regional level, which means in general at the basin scale. Due to the competition of all water users of a river basin, especially in water scarce regions, a comprehensive approach is needed regarding not only agricultural purposes but also domestic, industrial, and ecological aspects.

Recent approaches for sustainable water management at the basin scale are using the framework of an integrated water resources management (IWRM) by combining surface, groundwater, and unsaturated flow modelling as tools for the decision making, the development of decision support systems, e.g., to improve planning and management in large irrigation schemes, the involvement of multiple decision tools to find conflict resolutions, or the integration of multi-discipline aspects into a web-enabled spatial Decision Support System (DSS). Other researchers focused on the analysis of irrigation and environmental quality impact at the basin level, and adopted multiscale modelling tools for solving conflicts in rural basins with irrigation water uses. To solve conflicts under different water users in a developing country, conceptual frameworks for a watershed based institutional approach 
were developed including participatory integration and cooperative solutions.

The objective of this publication is to review the state of art on water management approaches for sustainable irrigation at the basin scale under semi-arid and arid climatic conditions, with main emphasis on Latin America, but including selected case studies of other arid and semiarid regions in the world. As IWRM is an interdisciplinary approach and used for very different case studies, the main emphasis is given to IWRM approaches for sustainable irrigation and their environmental aspects. But first a short comment on the actual state of IWRM worldwide and a brief analysis of general IWRM applications in Latin America is given.

\section{THE CONCEPT OF INTEGRATED WATER RESOURCES MANAGEMENT (IWRM)}

Integrated water resources management (IWRM) was defined by the Global Water Partnership (GWP, 2000) as "a process which promotes the coordinated development and management of water, land and related resources, in order to maximize the resultant economic and social welfare in an equitable manner without compromising the sustainability of vital ecosystems."

Jonch-Clausen (2004) offered a good general description of IWRM (why, what, and how). He explained necessity of IWRM Plans (pressures and competition for water requires improved management), the main targets and the way reaching the main aims (the IWRM process: start with the national context and urgent issues). To assure political interest and public support, the initial focus should be on crucial, urgent issues: flood management, irrigation water disputes or other such issues may be entry points. In the annex Jonch-Clausen (2004) enclosed short case studies of some countries (including Central America) explaining how they developed their IWRM planning.

At a first glance, the concept of IWRM looks attractive, but a deeper analysis brings out many problems, both in concept and implementation, as Biswas (2004) stated: there is no agreement on its fundamental issues like what aspects should be integrated, how, by whom, or even if such integration in a wider sense is possible. In a "second look" Biswas (2008c) analysed the current directions of IWRM and repeated his critical view of the popular concept and the problems of implementation in the real world. Grigg (2008) gave a more detailed description of the complexity and the difficulties of implementation at different levels. After his analysis of actual problems he offered another concept for integration of IWRM in different sectors. Coordination across geographic areas is recognized as a special challenge of integration. If institutional barriers are overcome, actual improvements in water stewardship may result.

Arecent comment on the implementation gap of IWRM by Mitchell (2009) stated that failure is not everywhere; examples exist of successful implementation, even in the face of difficult circumstances. Furthermore, he pointed out that we need to systematically identify variables and conditions which create gaps and determine how to resolve them, so that "best practice" can be enhanced.

\section{IMPLEMENTATION OF IWRM IN LATIN AMERICA}

In 2008 a workshop was organized in Rio de Janeiro, Brazil, to review the status and extent of implementation of IWRM in Latin American countries in order to determine whether the societal objectives of water management are being fulfilled better than before in a timely, costeffective, and socially acceptable manner (Biswas et al., 2008). As a result, it was concluded that the concept of IWRM has proved to be hard to implement, even though IWRM is now a legal requirement in some Latin American countries, with penalties for noncompliance (Biswas, 2008a). The papers of the workshop and the resulting discussions clearly indicated that in terms of concept and implementation, IWRM at present has significantly more questions than answers. Biswas (2008b) stated that, what is now needed is an objective assessment of the applicability of IWRM. It may work for micro-scale projects, but there is no evidence that it will work for macro- or meso-scale policies on a long term basis.

García (2008) examined in his paper for the workshop several examples of implementation of IWRM in Latin America. Most of these efforts have been focused at the constitutional level and even if they are strong in concepts, few actions meaningful for the end-user have resulted so far. There is a tendency to be heavy on diagnostics but weak in solutions and a gap still exists between papers and actions.

In another contribution to the workshop Braga and Lotufo (2008) applied the IWRM concept to develop an integrated water resources river basin plan for the Sâo Francisco river basin in Brazil. The paper breaks down the concept to consider the multiple objectives and uses of water, the incorporation of other sectors in the planning process and the involvement of stakeholders in the decision-making process. The preparation of the plan involved a large number of stakeholders. As a result, besides significant progress in some aspects, the lack of definition concerning water allocation affects the performance of the whole set of IWRM instruments. Braga and Lotufo (2008) evaluated their plan actually as an initial landmark: seeking basin sustainable development is 
principally seen as a process of activation and channelling of the social forces, an exercise of initiative and creativity, and an improvement of the cooperation and interaction skills of the different players who live in the basin.

Scott and Banister (2008) described the dilemma of water management development in Mexico, analysing the current decentralisation process. Although important advances have been made with irrigation management transfer, river basin councils, nascent user participation in groundwater management, and water and energy legislation, IWRM remains an elusive goal, principally due to inherent institutional and procedural contradictions in water resource allocation.

Other contributions of the workshop on IWRM application in Latin America for case studies in Mexico (Silva, 2008) and Colombia (Blanco, 2008) underline the actual problems of implementation in practicing integrated water resources management.

The fundamental demand of IWRM in hydrological basins is the creation of a participative work frame for decision making, where all the water-using sectors, including the environment, are represented. A recent publication on a case study in Mexico by Silva-Hidalgo et al. (2009) analyze the basic characteristics that mathematical basin models must have in order to satisfy the requirements of IWRM. The results of the analysis indicate that models for IWRM must be accessible to nonexpert users, integrate different viewpoints, representing adequately the problem to be solved, in addition be flexible and have a structure focused on practical solutions.

Due to the worldwide discussion about the problems of implementation of IWRM concepts at the basin level, recently a handbook as a practical guide was published (GWP-INBO, 2009) to overcome some of the existing hurdles.

\section{INTEGRATED WATER RESOURCES MANAGEMENT FOCUSSED ON SUSTAINABLE IRRIGATION}

Despite the general discussion, how to implement the IWRM concept into the different levels of existing decision structure of the real world, several case studies on water resources management for sustainable irrigation under semi-arid and arid conditions have been published. Examples in selected areas of Latin America and other arid and semiarid regions in the world are presented.

Irrigated agriculture notably increases crop productivity, but consumes high volumes of water and may induce off-site pollution of receiving water bodies. Causapé et al. (2004a) analysed the quality of irrigation and prescribed recommendations aimed at improving irrigation management and reducing the off- site pollution from an irrigation district located in the Ebro River Basin, Spain. The authors concluded that the three most important variables determining the quality of irrigation and the volume of irrigation return flows in the studied basins are (i) soil characteristics, (ii) irrigation management and irrigation system, and (iii) crop water requirements. Therefore, the critical recommendations for improving the quality of irrigation are to (i) increase the efficiency of flood irrigation, (ii) change to pressurized systems in the shallow and highly permeable soils, and (iii) reuse of drainage water for irrigation within the district. These management strategies will conserve water of high quality in the main reservoir and will decrease the crop water deficits and the volume of irrigation return flows, therefore, minimizing the off-site pollution from this irrigation district.

The legal framework in the European Union (EU) is faced today with the new Water Framework Directive (WFD) that sets up new criteria for water management, regulation, and pricing. The aim of Bazzani et al. (2004) is to analyze the problem of water regulation in agriculture in connection to the WFD. This is done by setting up and testing a simulation model based on the integration of a mathematical programming model at farm level and an optimal regulation model at the level of irrigation boards. The model allows quantifying water demand and optimal regulation from the policy maker's point of view. When implementing both full cost recovery and the polluter pays principle, the results show likely major impacts of water pricing on farm income and employment. The optimal policy is a combination of pricing instruments related at the same time to crop mix, water consumption, and pollution. Altogether, economic, social, and environmental issues have to be carefully considered in order to design suitable water policies.

Other researchers focused on the analysis of irrigation and environmental quality impact at the basin level (Causapé et al.,2004b), and adopted multi-scale modelling tools for solving conflicts in rural basins with irrigation water uses (Victoria et al., 2005). To solve conflicts under different water users in a developing country, Randhir and Genge (2005) developed a conceptual framework for a watershed based institutional approach including participatory integration and cooperative solutions.

Vishnudas et al. (2005) have presented an analytical framework that helps to understand the different aspects and elements of sustainable watershed management and their interactions. Each element has been examined as to how it affects sustainability in relation to the other elements. The framework helps to reveal the important factors contributing to land and water management and the livelihood of the people. The framework outlined should be applicable to watershed evaluation, not only 
in Kerala in South India, but also elsewhere in the world with similar situations. The research demonstrated the "chain of sustainability in watershed management", containing natural resources, technology, institution, and economics. To attain sustainable natural resource use, an integrated approach is essential. Sustainable watershed management may combine sustainable resource use with rural development and poverty alleviation.

Álvarez et al. (2005) described the implementation of the European Union's WFD through a National Irrigation Plan in Spain, especially the sustainable and integrated use of water resources. The results of a questionnaire were used as the basis for a water management model and for analysing the ongoing monitoring of irrigation use in this region. A management model is developed as an interdisciplinary approach, namely to promote long-term social and economic development and at the same time ensure long-term environmental protection.

An analysis for sustainability in management of water scarce basins was presented by Harmancioglu et al. (2008). They studied the case of the semiarid Gediz River Basin in Turkey within the scope of two EU projects, where water scarcity is a major problem like in most river basins of the Eastern and Southern Mediterranean due to rapid demographic and economic development, urbanization, industrialization, tourism, and inefficient agricultural activities, which is the dominant water user. Their approach is based on a multi-sectoral integration of quantitative and qualitative analysis, combining advanced tools of quantitative systems engineering, based on numerical simulation models, with methods of environmental, socioeconomic and policy impact assessment, using rule-based expert systems technology and interactive decision support methods. The paper presented the results of the analysis of current situation and of scenarios of possible future changes for the study region.

The pressure of human population and patterns of development frequently jeopardize the integrity of river systems worldwide. In such cases an IWRM approach is essential, as presented recently by Doummar et al. (2009) for the Lower Litani River Basin in Lebanon. Their EU supported study explored the ways in which multiple environmental, economic, and social benefits can be achieved. They concluded that the effectiveness of the IWRM process depends on the quality and quantity of data collected in the field, which is usually sparse, particularly in developing countries.

A system dynamics analysis for managing a river basin with semi-arid climate and large agricultural, industrial, and domestic water uses was presented recently by Madani and Mariño (2009). The Zayandeh-Rud river basin in central Iran is an example of a complicated watershed system where the lack of complete knowledge about all the interacting subsystems has led to failure of the policy makers in addressing the water shortage in the basin. The application of system dynamics provided a unique framework for integrating the disparate physical, socio-economic and political systems, offering different scenarios and solutions of the regional problems.

\section{SPECIAL TOOLS FOR DECISION SUPPORT AND SUSTAINABLE IRRIGATION}

Efficient water management is one of the key elements in successful operation of irrigation schemes in arid and semiarid regions. Kumar and Singh (2003) presented an integrated water management model, which was developed by combining an unsaturated flow model and a groundwater simulation model. It served as a tool for decision making in irrigation water management to maintain the water tables at a safe depth. The integrated model was applied on a regional scale in India for serious waterlogging and salinity problems. The model was used to study the long-term impact of two water management interventions related to the canal irrigation system - change in pricing system of irrigation water, and water supply according to demand - on the extent of waterlogging risk. The implementation of the proposed water pricing policy would pose no problem in fitting into the existing irrigation system, and thus it would be easier to implement, compared to the water supply according to demand strategy, when taking technical, financial, and social considerations into account.

Lorite et al. (2003) developed a simulation model for the analysis and evaluation of the irrigation management of an irrigated zone in Córdoba, Spain. The simulation model is used together with an indicator of functional conditions and allows a first evaluation of the irrigation area.

Water resources planning involve groups or institutions having differing objectives, responsibilities, and interests, and it requires collaboration for conflict resolution. Cai et al. (2004) discussed the characteristics and modelling requirements of conflict resolution in water resources planning. A method based on compound models is proposed for regional water resources planning involving multiple decision makers. This method combines modelling techniques, such as multi-objective analysis, multi-criteria and multi-participant decision methods, and supports plan generation and evaluation, individual and group preference elicitation, and negotiation taking aim at a consensus plan. The method demonstrated that computer models can be effective and useful for group decisions in water resources planning by facilitating information sharing, participative model development, and learning processes. 
Adaptation strategies to climate change have been explored using a linked field-scale basin-scale modelling framework for a basin in Sri Lanka. An integrated approach was followed concentrating on enhancement of food security and preservation of environmental quality (Droogers, 2004). Impact and adaptation strategies were evaluated with a coupled modelling framework based on the soil-water-atmosphere-plant (SWAP) field scale model and the water and salinity basin model (WSBM). Weather extremes, caused by climate change, will be more profound in the future, making adaptation strategies necessary. Results from the modelling framework have been presented in a format accessible to water resources managers and policy makers to enable them to make sound decisions on the required adaptation strategies.

Ortega et al. (2005) have discussed the main methodological aspects and results obtained from the activity of the Irrigation Advisory Service for Farmers (SIAR) of the semi-arid region Castilla-La Mancha, Spain. SIAR upgrades farmers' capacities and awareness, thus minimizing the negative environmental impacts of irrigation, decreasing the production costs and contributing to the sustainability of irrigated agriculture in the area. Water-scarce areas are where the SIAR advice is more closely followed by the farmers and irrigation performance indicators are highest. Among the results obtained, the most important is the improvement of water use. However, technical, social and economic limitations are relevant, and constitute a handicap to achieve the objectives of the advisory service.

For the implementation of the EU WFD, especially the correct management of the water resources and the involvement of the stakeholders in the decision process Martín de Santa Olalla et al. (2005) described the development of a Bayesian Networks to solve environmental problems. The main problem in the application region is the risk of overexploitation of the local aquifer, brought about by a considerable increase of the surface area of irrigated arable land. The results offered by the tool show that the current situation is nonsustainable. Two solutions are discussed, to decrease the current volume of groundwater for irrigation and to replace groundwater by surface water.

Victoria et al. (2005) are adopting modelling tools focusing multi-scale problem solving in basins with irrigation water uses. Multi-scaling may help conflict solving since an approach to the scale, close to that where conflicts occur, is more appropriate for understanding and dealing with related problems. It is applied to rural basins in Brazil, where competition among agricultural and non-agricultural uses is high during periods when water availability is scarce. The approach referred to the field scale modelling relative to agricultural demand considering soils, crops and crop patterns, cropping techniques, environment factors, irrigation practices and restrictions to water use (ISAREG model), and basin scale water resource planning models, including nonagricultural uses: urban, domestic, industrial, recreational, and other uses (SAGBAH model). Analyses of scenarios require a multi-scale approach. It results a tool that produces a distributed spatial analysis of the agricultural demand, while non-agricultural uses refer to sub-basins. The multi-scale analyses allows to improve knowledge on the processes relative to water use, to understand spatial and temporal variations, to simulate with historical data and for different scenarios, including those that may result from climate change.

The technology of irrigated agriculture has often been controversial. The development agencies would praise its productivity, as only $18 \%$ of the world's cultivated land is irrigated but produces roughly $33 \%$ of the world's human food supply. Environmental and ecological concerns cite the degradation of natural landscapes, elimination of floodplains and wetlands, and profound impacts on wildlife habitats. Oad and Kullman (2006) have used the ecological approach, that "irrigation should be viewed as a manmade ecological system, in which land and water are modified to increase agricultural production"; to study the Middle Rio Grande irrigated landscape (USA). Their paper presented findings related to opportunities in the agricultural sector to reduce water diversions from the river, primarily by changing the practice of continuous canal water delivery to rotational water delivery. By applying this approach in the study area more water is now available in the river for better ecology in general and for better fish and wildlife habitat in particular.

According to Zarghaami (2006) effective water management requires a comprehensive consideration of all related aspects, e.g., technical, social, environmental, institutional, political, and financial. The rising of population in Iran put significant pressure on authorities and infrastructures to provide water. Without improvement in water management, irrigation demand will continue to increase, water supplies will diminish and the population pressure will decay infrastructure. His paper described compromise programming to solve multi-criteria decision making in irrigation planning for an irrigation area in the North of Iran, environmental aspects and an approach for reducing social conflicts are included. This research shall be the basis for a successful implementation of IWRM in irrigation planning.

Schoups et al. (2006) investigated strategies to alleviate the effects of droughts on the profitability and sustainability of irrigated agriculture. These strategies included conjunctive management of surface water and groundwater resources, and engineered improvements 
such as lining of irrigation canals and addition of regional pumping well capacity. A spatially distributed simulationoptimization model was developed for an irrigated system consisting of multiple surface water reservoirs and an alluvial aquifer. The simulation model consists of an agronomic component and simulators describing the hydrologic system. The physical models account for storage and flow through the reservoirs, routing through the irrigation canals, and regional groundwater flow. The agronomic model described crop productivity as a function of irrigation quantity and salinity, and determined agricultural profit. A profit maximization problem was formulated and solved using large-scale constrained gradient-based optimization. Groundwater could have been more heavily relied upon and surface water allocation capped at a sustainable level as an operating rule. The benefits of a greater reliance on groundwater pumping by installing additional wells were limited due to pumping restrictions near the coast to avoid seawater intrusion and due to increased pumping costs. The model was applied to the conjunctive surface water/groundwater problem in the Yaqui Valley, an irrigated agricultural region in Sonora, Mexico.

Distributed eco-hydrological modelling (Singh et al., 2006a) can provide a useful tool to evaluate the performance of irrigation systems at different spatial and temporal scales. The Sirsa district, India, has been selected for a case study with typical problems of canal water scarcity, poor groundwater quality, rising and declining groundwater levels, and sub-optimal crop production. The field scale eco-hydrological model SWAP including detailed crop growth simulations was extended in a distributed manner to quantify the required hydrological and biophysical variables for all combinations of weather crop - soil - irrigation in the study area. Field experiments, satellite images and existing geographical data were used to aggregate the representative input parameters of all so-called homogeneous 'simulation units' and their boundary conditions. The simulated water and salt limited crop yields showed a good correspondence with the independent crop yields data obtained from remote sensing, field measurements and statistical records. Factors responsible for low water productivity in Sirsa district included a high percentage of soil evaporation into evapotranspiration, percolation from fields and seepage losses from the conveyance system. The study also revealed a large variation of net groundwater recharge and salt build-up over different canal commands, which threatens the sustainability of irrigated agriculture in Sirsa district.

Sánchez et al. (2006) used an irrigation district as a study case for the application of a Decision Support System (DSS) called FACILITADOR. It is a software tool to support decision making processes with the use of decision alternatives, helping to the solution of the overall problem of irrigation water productivity. First water needs to be priced and to train water users and delivering by volume.

Tejera-Gimeno and García-Rodríguez (2006) presented a watershed management methodology based on land-use planning model, whereby sustainability criteria were introduced according to the capacity of the environment to support intervention in the watershed.

In the last two decades, Mexican irrigated agriculture has faced large changes as a result of recurrent droughts and the transfer of irrigation management from the federal government to Water User Associations (WUA). The associations face a great challenge in the efficient operation of water distribution networks and use of water. Under water scarcity conditions, new irrigation management strategies must be implemented to estimate irrigation requirements at field scale and integrate them into several operating levels of the irrigation network. Ojeda-Bustamante et al. (2007) have developed a computer tool, Spriter, and transferred it to several WUA of Mexican irrigation districts. The system allowed the dynamic generation of digital map reports based on a Geographical Information System (GIS), as mapping of physical features of fields is linked to the main database. Software applications are presented to illustrate the advantages of using spatial information technologies to improve water management in large irrigation districts.

Hussain et al. (2007) provided an overview of the issues in and approaches to measuring and enhancing the value of agricultural water in large irrigated river basins. They developed a framework and a set of indicators for valuing agricultural water by looking into various dimensions and underlying key factors that influence the value of water at micro, meso and macro levels. In addition, the research compiles recent estimates of the value of agricultural water, and it outlines measures for enhancing the value of agricultural water.

Gürlük and Ward (2009) discussed a basin scale analysis of the Nilüfer River Basin of Turkey, where agricultural, urban, and environmental users compete for scarce water in an environment where climate change and food security present large and growing challenges. They examined the policy-informing role that can be played by the development and use of basin scale models. Their paper presented the results of a basin scale dynamic nonlinear programming model that addresses economic efficiency, climate change, and food security. The modelling approach provides a general framework for formulating water management policies, consistent with the principles underlying the European WFD.

The explosive population growth in western US, the 
emerging additional need for water for environmental uses, and the national importance of the domestic food production are driving major conflicts between these competing water users. Oad et al. (2009) presented their ongoing research on efficient irrigation in the case of the Middle Rio Grande, where the irrigated agriculture has come under increasing pressure to reduce its water consumption. Their paper described formulation and implementation of a decision support system that can assist watershed managers to more efficiently plan and implement water delivery operations, using linear programming to find an optimum delivery schedule for irrigation canal service areas.

Gastélum et al. (2009) analyzed the problems of the Mexican Rio Conchos Basin, the largest tributary to the lower part of the Rio Grande/Rio Bravo Basin. They developed a decision support system as a semi-distributed model, based on System Dynamics, to evaluate several allocation alternatives for the main basin's users: Irrigation District and Water Treaty. The DSS application showed that understanding the effects of multiple interacting variables is necessary to develop good natural resource management policies.

An integrated approach is presented by Steward et al. (2009) to study the impacts of external forcing on irrigated agricultural systems in the semi-arid grasslands of the Central Plains of the United States of America. Individually, models are presented that simulate groundwater hydrogeology and econometric farm level crop choices and irrigated water use. The natural association between groundwater wells and agricultural parcels is employed to couple these models using GIS and open modelling interface protocols. This approach represent the first time that groundwater and econometric models of irrigated agriculture have been integrated and provides useful methods for decision making.

\section{IWRM FOR SALT AFFECTED IRRIGATED AREAS}

The Qingtongxia Irrigation District (QID) in China is one of the key agricultural bases in the arid and semiarid part of the Yellow River Basin. Water shortage is one of the main restrictions on agricultural development. In recent years, large amounts of water have been drawn from the Yellow River, which not only contributes to the severity of water shortages in the middle and downstream part of the Yellow River Basin, but also leads to the rise of the groundwater table and related waterlogging and salinisation of the farmland. Wang et al. (2004) focussed on the analysis of the effects of field groundwater table control under different irrigation water amounts on the soil water and salinity content and on relative crop yield.
The agro-hydrological model SWAP was used to analyse the water flow and salt transport for different groundwater table and irrigation scenarios. The results showed that high regional groundwater tables are the main reason for the large amount of drainage water and low crop yield. The salinity storage in the soil profile at the end of the growing season will increase when the irrigation amount is reduced, and when the groundwater table is lowered. To lower the field groundwater to the target water table is an effective way to increase crop yield.

Extensive field data and calibrated flow and salttransport models characterize the spatial and temporal patterns of salinity and waterlogging in an irrigated river valley. Burkhalter and Gates (2005) showed results of a monitoring of water quality. Beyond problem identification, the developed database and models provided a basis for effectively addressing these problems through a systematic and comparative assessment of alternative solutions.

Agricultural production along the Lower Arkansas River of Colorado is being negatively affected as a result of irrigation induced waterlogging and soil salinisation. Houk et al. (2006) presented an estimate of these damages along a study area by linking a detailed hydrologic model, calibrated from extensive field data, to an economic model that evaluates productivity losses within the study region. The hydrologic model provides a detailed estimate of the soil salinity levels and water table depths that occur throughout the region. Using geographic information system (GIS) software, the output from the hydrologic model is converted into field level data, which are used to estimate the damages that are occurring upon each irrigated field across the study area. The impact of soil salinity on agricultural production is estimated.

Potential solutions to high soil salinity levels and waterlogging problems are investigated on a regional scale using calibrated finite-difference flow and mass transport modelling for a portion of the Lower Arkansas River Valley in Colorado/USA (Burkhalter and Gates, 2006). A total of 38 alternatives incorporating varying degrees of recharge reduction, canal seepage reduction, subsurface drainage installation, and pumping volume increases are modelled. Six performance indicators are used to evaluate the effectiveness of these alternatives in improving agroecological conditions, compared to existing conditions. Estimated groundwater salinity changes, reduction in total salt loading to the river, increase in average regional crop yield, and changes in net water consumption indicate the potential for marked regional-scale enhancements to the irrigation-stream-aquifer system.

Singh et al. (2006b) focussed on the identification of appropriate strategies to improve water management and productivity in the Sirsa district, India. The field 
scale eco-hydrological model SWAP, in combination with field experiments, remote sensing and GIS, has been applied in a distributed manner generating the required hydrological and biophysical variables to evaluate alternative water management scenarios at different spatial and temporal scales. Improved crop husbandry in terms of improved crop varieties, timely sowing, better nutrient supply and more effective weed, pest and disease control, will increase crop yields and water productivity in this district. The scenario results further showed that reduction of seepage losses will improve significantly the long term water productivity, halt the rising and declining groundwater levels, and decrease the salinisation in Sirsa district.

Irrigated agriculture notably increases crop productivity but may negatively impact river water quality because of the salt and agrochemical loadings in irrigation return flows. Isidoro and Araguiés (2007) evaluated the salinity and ion concentrations in 31 river stations of the Ebro basin, characterized the quality of waters for irrigation, and analysed the influence of irrigation on river water quality. Due to the low salinity of most irrigation waters, maximum irrigation efficiencies are attainable in the Ebro basin without compromising crop yields due to root zone soil salinisation.

\section{IWRM FOR POLLUTION PROBLEMS OF IRRIGATED AREAS}

The objective of Jamieson et al. (2004) was to present and evaluate current approaches to modelling the microbial quality of surface waters in rural watersheds. A complete watershed scale microbial water quality model includes subroutines which (i) characterize the production and distribution of waste and associated microorganisms, (ii) simulate the transport of microorganisms from the land surface to receiving streams, and (iii) route microorganisms through stream networks. Current watershed scale models only account for microbial transport to surface waters through overland flow and ignore subsurface transport. The movement of microorganisms on the soil surface was predicted using simple empirical equations or by assuming that microorganism transport is only associated with sediment erosion. The simulation of microorganism survival and transport in receiving streams is complicated by sediment/microorganism interactions. More research is needed to be able to quantitatively assess and model microbial processes in alluvial streams.

Causapé et al. (2004b) discussed salt and nitrate pollution of receiving water bodies caused by irrigation return flows. The objectives of this study were to perform a salt and nitrogen mass balance at the hydrological basin level and to quantify the salt and nitrate loads exported in the drainage waters and the groundwater. The off-site impact ascribed solely to irrigation in the analysed basins was estimated in the soil drainage water. A low irrigation efficiency coupled to an inadequate management of nitrogen fertilization are responsible for the low-salt, high-nitrate concentrations in soil and surface drainage outflows from the studied basins. In consequence, higher irrigation efficiencies, optimized nitrogen fertilization and the reuse for irrigation of the low-salt, high-nitrate drainage waters are key management strategies for a better control of the off-site pollution from the studied irrigation district.

Agriculture is the main non-point polluter of groundwater in irrigated areas as fertilizers and other agrochemicals are the main contaminants in the water that drains out of the root zone to recharge the aquifer. The concentration of nitrates in the percolated water depends on the distributed field water and nitrogen balances over the area. Its concentration in the groundwater depends on the total recharge, pollution loading, groundwater flow and solute transport within the aquifer. The development and application of a GIS based decision support framework that integrates field scale models of these processes for assessment of non-point-source pollution of groundwater in canal irrigation project areas was presented by Chowdary et al. (2005). GIS was used for representing the spatial variations in input data over the area and map the output of the recharge and nitrogen balance models. The latter were used to provide the spatially distributed recharge and pollutant load inputs to the distributed groundwater flow and transport models, respectively. Alternate strategies for water and fertilizer use can be evaluated using this framework to ensure long-term sustainability of productive agriculture in large irrigation projects. The development and application of the framework was illustrated by taking a case study of a large canal irrigation system in India (Chowdary et al., 2005).

Irrigated agriculture may negatively affect groundwater quality and increase off-site salt and nitrate contamination. Management alternatives aimed at reducing these potential problems were analysed in an irrigation district in Spain by monitoring of wells and modelling the hydrological regime in a representative well of the studied aquifer. The groundwater depth (GWD) was consistently simulated by the groundwater BAS-A model. Model results indicate that an increase in irrigation efficiency and the pumping of groundwater for irrigation will decrease GWD and aquifer's discharge. These recommendations will save good-quality water in the studied reservoir, will be beneficially economical to farmers, and will minimize off-site salt and nitrogen contamination (Causapé et al., 2006). 
Shaki and Adeloye (2006) described an analysis of data on water quality, quantity and groundwater levels from several water wells serving an irrigation project in Libya. Libya is considered as one of those countries having limited renewable water resources, because most parts of the country are either semi-arid or arid. The consequent over-reliance on groundwater for meeting the ever-increasing water demand has resulted in the excessive depletion of the fresh groundwater stock. The continued water withdrawal from the aquifer system over the last three decades has resulted in significant lowering of the groundwater table in the study area.

Ji et al. (2006) have demonstrated that over the last decades, man-made oasis have developed rapidly in various inland river basins of China. With the increasing human demand for water, the contradiction between water demand and water supply is becoming increasingly acute and the amount of groundwater usage significantly increased. Human activities cause environmental problems, such as water quality deterioration, vegetation degradation, soil salinisation and land desertification. It is suggested that modernized irrigation technology and new regulation to cover water resources management and allocation with the river basins are urgently needed to achieve a sustainable development. The aim of this study was to analyze the impact of the development of water resources on the environment in arid inland river basins in North-western China.

Fernández et al. (2006) presented a watershed scale lumped parameter hydrology and water quality model that includes an uncertainty analysis component was developed and tested on a lower coastal plain watershed in North Carolina, USA. Uncertainty analysis was used to determine the impacts of uncertainty in field and network parameters of the model on the predicted outflows and nitrate-nitrogen loads at the outlet of the watershed. The model linked DRAINMOD field hydrology and a spatially distributed routing model. Uncertainty analysis indicated that uncertainty in stream velocities, decay coefficient and field exports significantly contributed to the uncertainty in the predicted outlet flows, loads and mean watershed delivery ratio.

In order to gain knowledge about appropriate approaches for integrating natural resources management with rural development strategies, the study of Rubiano et al. (2006) detailed a framework designed to implement research and development activities in the Fúquene watershed of Colombia. The framework integrates key spatial information, available at different scales for the site, to facilitate envisioning different land-use scenarios and their impacts upon water resources. Strategic alliances and collective action are implemented to test the feasibility of environmental and economic alternatives.
The approach shows that integration is accomplished only when different scales of decision-making are considered and if activities at plot detail are linked with effects at the watershed scale.

\section{CONCLUSIONS}

The revised publications show that for a sustainable water resources management at the basin scale an integrated and interdisciplinary approach is essential. Irrigated agriculture is in competition with other water users, e.g. drinking water supply and industry. The overall water management of an irrigated region has to be analysed by using economic, social, and environmental aspects. All stakeholders have to be included for ensuring the improvement of the sustainability of irrigation.

In Europe the Water Framework Directive is demanding an interdisciplinary approach, namely to promote long-term social and economic development and at the same time ensure long-term environmental protection, therefore the involvement of all affected stakeholders is necessary.

The concept of Integrated Water Resources Management (IWRM) was promoted inter alia by the Global Water Partnership (GWP), but on a recent LatinAmerican workshop on IWRM it was concluded that the concept has proved to be hard to implement. The discussion indicate that application of IWRM must be flexible for new development, accessible to non-expert users, integrate different viewpoints, and should have a structure focused on practical solutions.

Irrigation planning at the basin scale has always to consider the other objectives of IWRM. In developing countries the research should deliver approaches to increase the awareness of the farmers for environmental impacts, while considering the technical, social and economic limitations. Sustainable watershed management may combine sustainable use of resources with rural development and poverty alleviation.

Only a small amount of the reviewed papers present investigations at the basin scale in Latin America. More papers are showing research results of projects in South Europe, Australia, Asia and the USA. In investigations in Latin America the environmental impact is mostly analysed in some plots of the basin, but the environmental impact on the whole basin is not considered.

Agriculture is the main non-point polluter of groundwater in irrigated areas as fertilizers and other agrochemicals are the main contaminants in the water that drains out of the root zone to recharge the aquifer. Low irrigation efficiency coupled to an inadequate management of nitrogen fertilization is the main producer of contamination. Several papers present that the main 
problems are waterlogging and salinisation, only a small amount of papers is discussing the contamination by nutrients and pesticides at the basin scale. Some publications show the risk of overexploitation of the local aquifer and give approaches for efficient operation of water distribution networks. Other papers show the importance of a good distribution of the water resources in a basin, e.g., they suggest a conjunctive management of surface and groundwater for irrigation to ensure the sustainable use of the water resources. Some publications promote the reuse of drained water for downstream irrigation.

Many publications present the development of models, advisory services and decision support systems at a high technical level. For example, multi-criteria decision making models are developed for irrigation planning. One research combines an unsaturated flow model and a groundwater simulation model to serve as a tool for decision making in irrigation water management, to maintain the water tables at a safe depth, and to improve salinity problems. Irrigation scenarios are used to show the impact of different irrigation planning.

Several projects use GIS to handle data and to visualise their research results. In some investigations satellite images and remote sensing are used to compensate lacks in data bases.

In general, comprehensive investigations on sustainable water resources management for irrigation at the basin scale are still scarce in Latin America, but the legal pressure, first results and an increasing awareness of the stakeholders indicate a high potential for improved approaches and tools.

\section{RESUMEN}

Manejo integrado de recursos hídricos para riego sustentable a nivel de cuenca. El objetivo de esta publicación es revisar el estado del arte de los diferentes enfoques que se han usado para lograr un manejo integrado de los recursos hídricos (MIRH) asociados a una agricultura de riego sustentable a nivel de cuenca en condiciones áridas y semiáridas, con énfasis en Latinoamérica, pero incluyen casos de estudio de otras regiones similares del mundo. En Latinoamérica el concepto general de MIRH ha resultado difícil de implementar. De los estudios de casos, se recomienda desarrollar este enfoque desde una escala menor a una mayor orientándose al usuario final. MIRH es un enfoque interdisciplinario usado para diferentes objetivos, siendo el mayor énfasis el lograr una agricultura de riego sustentable. Esta revisión demuestra que en Latinoamérica los impactos ambientales son principalmente analizados a escala predial y muy poco considerados a escala de cuenca. Muchas publicaciones presentan el desarrollo de modelos, criterios de apoyo y herramientas para el soporte de decisión a un alto nivel técnico. Algunos artículos presentan estudios de los aspectos ambientales de una agricultura de riego sostenible, especialmente en las zonas afectadas por salinización. Modelos de soporte de decisión que usan multicriterios han sido desarrollados para la planificación de sistemas de riego y son usados para evaluar el impacto de diferentes decisiones de manejo de sistemas. En general, se puede concluir que existen escasos enfoques integrales de manejo en Latinoamérica.

Palabras clave: manejo recursos hídricos, cuenca, sustentabilidad, riego.

\section{LITERATURE CITED}

Álvarez, C.J., J.J. Cancela, and M. Fandiño. 2005. Characterization of irrigated holdings in the Terra Chá Region of Spain: A first step towards a water management model. Water Resour. Manage. 19:2336.

Bazzani, G.M., S. Di Pasquale, V. Gallerani, and D. Viaggi. 2004. Irrigated agriculture in Italy and water regulation under the European Union Water Framework Directive. Water Resour. Res. 40, W07S04, doi:10.1029/2003WR002201.

Biswas, A.K. 2004. Integrated water resources management: A reassessment. Water Internat. 29:248-256.

Biswas, A.K. 2008a. Editorial: Integrated water resources management in Latin America. Int. J. Water Resour. Dev. 24:1-4.

Biswas, A.K. 2008b. Integrated water resources management: Is it working? Int. J. Water Resour. Dev. 24:5-22.

Biswas, A.K. 2008c. Current directions: Integrated water resources management - a second look. Water Internat. 33:274-278.

Biswas, A.K., B.P.F. Braga, C. Tortajada, and M. Palermo. 2008. Integrated water resources management in Latin America. Int. J. Water Resour. Dev. 24(1) Special Issue.

Blanco, J. 2008. Integrated water resources management in Colombia: Paralysis by analysis? Int. J. Water Resour. Dev. 24:91-101.

Bouwer, H. 2002. Integrated water management for the $21^{\text {st }}$ century: Problems and solutions. J. Irrig. Drain. Eng. 128:193-202.

Braga, B.P.F., and J.G. Lotufo. 2008. Integrated river basin plan in practice: The Sâo Francisco River Basin. Int. J. Water Resour. Dev. 24:37-60.

Burkhalter, J.P., and T.K. Gates. 2005. Agroecological impacts from salinization and waterlogging in an irrigated river valley. J. Irrig. Drain. Eng. 131:197-209. 
Burkhalter, J.P., and T.K. Gates. 2006. Evaluating regional solutions to salinization and waterlogging in an irrigated river valley, J. Irrig. Drain. Eng. 132:21-30.

Cai, X., L. Lasdon, and A.M. Michelsen. 2004. Group decision making in water resources planning using multiple objective analysis. J. Water Resour. Plng. and Mgmt. 130:4-14.

Causapé, J., D. Quílez, and R. Aragües. 2004a. Assessment of irrigation and environmental quality at the hydrological basin level: I. Irrigation quality. Agric. Water Manage. 70:195-209.

Causapé,J.,D.Quílez, and R.Araguiés. 2004b.Assessment of irrigation and environmental quality at the hydrological basin level: II. Salt and nitrate loads in irrigation return flows. Agric. Water Manage. 70:211-228.

Causapé, J.,D. Quílez, and R.Araguiés. 2006. Groundwater quality in CR-V irrigation district (Bardenas I, Spain): Alternative scenarios to reduce off-site salt and nitrate contamination. Agric. Water Manage. 84:281-289.

Chowdary, V.M., N.H. Rao, and P.B.S. Sarma. 2005. Decision support framework for assessment of non-point-source pollution of groundwater in large irrigation projects. Agric. Water Manage. 75:194-225.

Doummar, J., M.A. Massoud, R. Khoury, and M. Khawlie. 2009. Optimal water resources management: Case of lower Litani River, Lebanon. Water Res. Manage. 23:2343-2360.

Droogers, P. 2004. Adaptation to climate change to enhance food security and preserve environmental quality: Example for Southern Sri Lanka. Agric. Water Manage. 66:15-33.

Fernandez, G.P., G.M. Chescheir, R.W. Skaggs, and D.M. Amatya. 2006. DRAINMOD-GIS: A lumped parameter watershed scale drainage and water quality model. Agric. Water Manage. 81:77-97.

Gastélum, J.R., J.B. Valdés, and S. Stewart. 2009. A decision support system to improve water resources management in the Conchos Basin. Water Resour. Manage. 23:1519-1548.

García, L.E. 2008. Integrated Water Resources Management: A 'Small' Step for Conceptualists, a Giant Step for Practitioners. Int. J. Water Res. Develop. 24(1):23-36.

GWP-INBO. 2009. A handbook for integrated water resources management in basins. Global Water Partnership and the International Network of Basin Organizations, Stockholm, Sweden.

Grigg, N.S. 2008. Integrated water resources management: balancing views and improving practice. Water Internat. 33:279-292.

Gürlük, S., and F.A. Ward. 2009. Integrated basin management: Water and food policy options for Turkey. Ecol. Econ. 68:2666-2678.
Harmancioglu, N.B., K. Fedra, and F. Barbaros. 2008. Analysis for sustainability in management of water scarce basins: The case of the Gediz River Basin in Turkey. Desalination 226:175-182.

Houk,E., M. Frasier, and E. Schuck. 2006. The agricultural impacts of irrigation induced waterlogging and soil salinity in the Arkansas Basin. Agric. Water Manage. $85: 175-183$.

Hussain, I., H. Turral, D. Molden, and M.D Ahmad. 2007. Measuring and enhancing the value of agricultural water in irrigated rives basins. Irrig. Sci. 25:263-282

Isidoro, D., and R. Aragüés. 2007. River water quality and irrigated agriculture in the Ebro Basin: An overview. Int. J. Water Resour. Dev. 23:91-106.

Jamieson, R., R. Gordon, D. Joya, and H. Leec. 2004. Assessing microbial pollution of rural surface waters - A review of current watershed scale modeling approaches. Agric. Water Manage. 70:1-17.

Ji, X., E. Kang, R. Chen, W. Zhao, Z. Zhang, and B. Jin. 2006. The impact of the development of water resources on environment in arid inland river basins of Hexi Region, Northwestern China. Environ. Geol. 50:793-801.

Jonch-Clausen, T. 2004. Integrated Water Resources Management and Water Efficiency Plans by 2005, Why, What and How? Global Water Partnership, Stockholm, Sweden. Available at http://www. gwpforum.org/gwp/library/TEC10.pdf (accessed May 2008).

Kumar,R., and J. Singh.2003. Regional water management modeling for decision support in irrigated agriculture. J. Irrig. Drain. Eng. 66:432-439.

Lorite, I., L. Mateos, y E. Fereres. 2003. Aplicación de un modelo de simulación a la evaluación de una zona regable. Rev. Ing. Agua 10(4):517-526.

Madani, K., and M.A. Mariño. 2009. System dynamics analysis for managing Iran's Zayandeh-Rud River Basin. Water Resour. Manage. 23:2163-2187.

Martín de Santa Olalla, F.J., A. Domínguez, A. Artigao, C. Fabeiro, and J.F. Ortega. 2005. Integrated water resources management of the hydrogeological unit "Eastern Mancha" using bayesian belief networks. Agric. Water Manage. 77:21-36.

Mitchell, B. 2009. Implementation Gap. IWRA update July 2009. Int. Water Res. Assoc. 3:7-12.

Oad, R., and R. Kullman. 2006. Managing irrigation for better river ecosystems - A case study of the Middle Rio Grande. J. Irrig. Drain. Eng. 132:579-586.

Oad, R., L. Garcia, K.-D. Kinzli, D. Patterson, and N. Shafike. 2009. Decision support systems for efficient irrigation in the Middle Rio Grande Valley. J. Irrig. Drain. Eng. 135:177-185. 
Ojeda-Bustamante, W., J.M. González-Camacho, E. Sifuentes-Ibarra, E. Isidro, and L. Rendón-Pimentel. 2007. Using spatial information systems to improve Water Management in Mexico., Agric. Water Manage. 89:81-88.

Ortega, J.F., J.A. de Juan, and J.M. Tarjuelo. 2005. Improving water management: The irrigation advisory service of Castilla-La Mancha (Spain). Agric. Water Manage. 77:37-58.

Randhir, T., and C. Genge. 2005. Watershed based, institutional approach to developing clean water resources. J. Amer. Water Resour. Assoc. 2:413-424.

Rubiano, J., M. Quintero, R.D. Estrada, and A. Moreno. 2006. Multiscale analysis for promoting integrated watershed management. Water Int. 31:398-411.

Sanchez, I., H. Macías, P. Heilman, G. Gonzalez C., S.F. Mendoza M., M. Inzunza, and J. Estrada A. 2006. Multiobjective planning in the irrigation districts of Mexico. A Decision support system application. Revista Ingeniería Hidráulica en Mexico 21:101-111.

Schoups, G., C.L. Addams, J.L. Minjares, and S.M. Gorelick. 2006. Sustainable conjunctive water management in irrigated agriculture: Model formulation and application to the Yaqui Valley, Mexico. Water Resour. Res., Vol. 42, W10417, doi:10.1029/2006WR004922, 2006.

Scott, C.A., and J.M. Banister. 2008. The dilemma of water management 'Regionalization' in Mexico under centralized resource allocation. Int. J. Water Resour. Dev. 24:61-74.

Shaki, A.A., and A.J. Adeloye. 2006. Evaluation of quantity and quality of irrigation water at Gadowa irrigation project in Murzuq Basin, Southwest Libya. Agric. Water Manage. 84:193-201.

Silva, P. 2008. Small-scale irrigation systems in an IWRM context: The Ayuquila-Armería Basin commission experience. Int. J. Water Resour. Dev. 24:75-89.

Silva-Hidalgo, H., I.R. Martín-Domínguez, M.T. AlarcónHerrera, and A. Granados-Olivas. 2009. Mathematical modelling for the integrated management of water resources in hydrological basins. Water Resour. Manage. 23:721-730.
Singh, R., R.K. Jhorar, J.C. van Dam, and R.A. Feddes. 2006b. Distributed ecohydrological modelling to evaluate irrigation system performance in Sirsa district, India II: Impact of viable water management scenarios. J. Hydrol. 329:714.723.

Singh, R., J.G. Kroes, J.C. van Dam, and R.A. Feddes. 2006a. Distributed ecohydrological modelling to the performance of irrigation system in Sirsa India: I. Current water management and productivity. J. Hydrol. 329:692-713.

Steward, D.R., J.M. Peterson, X. Yang, T. Bulatewicz, M. Herrera-Rodriguez, D. Mao, and N. Hendricks. 2009. Groundwater economics: An object-oriented foundation for integrated studies of irrigated agricultural systems. Water Resour. Research, Vol. 45, W05430, doi:10.1029/2008WR007149, 2009.

Tejera-Gimeno, R., and J.L. García-Rodríguez. 2006. Methodology for watershed management and planning: a new approach based on sustainable criteria. Revista Ingeniería Hidráulica en Mexico 21(1):43-58.

Victoria, F.B., J.S. Viegas Filho, L.S.Pereira, J.L. Teixeira, and A.E. Lanna. 2005. Multi-scale modeling for water resources planning and management in rural basins, Agric. Water Manage. 77:4-20.

Vishnudas, S., H.H.G. Savenije, and P. Van Der Zaag. 2005. A conceptual framework for sustainable watershed management. In ICID $21^{\text {st }}$ European Regional Conference, Frankfurt/Oder, Germany, and Slubice, Poland. 15-19 May 2005. International Commission of Irrigation and Drainage (ICID), New Delhi, India.

Wang, X., P.H.J. Hollanders, S. Wang, and S. Fang. 2004 Effect of field groundwater table control on water and salinity balance and crop yield in the Qingtongxia irrigation district, China. Irrig. Drain. 53:263-275.

Zarghaami, M. 2006. Integrated water resources management in Polrud irrigation system. Water Resour. Manage. 20:215-225. 